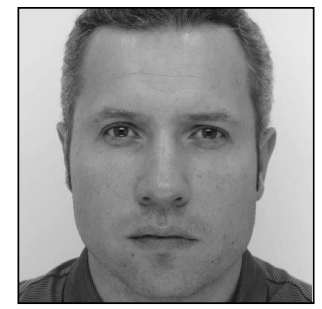

Janno Lahe

Professor

University of Tartu

\title{
German Transplants in Estonian Tort Law: General Duties to Maintain Safety
}

\section{Introduction}

The Law of Obligations Act ${ }^{* 1}$ (LOA) was passed in 2001 and entered force in Estonia on 1 July 2002. The authors of the commentary on the LOA have noted that the tort law provisions contained in the LOA are based on the tort law provisions of, above all, the German Civil Code, or Bürgerliches Gesetzbuch (BGB) ${ }^{*}$. However, instead of the provisions of the BGB, the tort law provisions of the LOA were inspired in actuality by the relevant German case law, legal theory, and proposals for reforming the tort law provisions of the BGB. ${ }^{*}{ }^{3}$

Indeed, even at first glance, the tort law provisions of the LOA and BGB look quite different. In some places, the differences are obvious. Just a few examples are that, unlike in German law, the tortfeasor has to prove the absence of fault under the LOA's Subsection 1050(1); the fault is substantiated subjectively under its Subsection 1050(2); the strict liability provisions are set out in special laws in Germany, but in Estonia this is done in the LOA; and, unlike the LOA's Section $1056^{*} 4$, German law does not set out general strict liability. The list of significant differences is considerably longer.

However, one could give just as many (if not more) examples of how the science and case law of German tort law or, broadly speaking, legal thinking has found its way into Estonian case law on torts and into Estonian legal scholarly texts. One example that stands out in particular involves the issue of the division of liability in a situation wherein mutual damage has been caused by two motor vehicles: regardless of the difference between their relevant provisions, the German and Estonian case law have come to be nearly identical in this field. ${ }^{*}$

This article is not intended to map or list all of the transplants from German tort law that have reached Estonian law or practice. Rather, it focuses on a transplant whose importance cannot be overestimated. This transplant is the concept of tort liability based on breach of the general duty to maintain safety. It is an issue whose importance is broader than that of individual questions: the recognition of general duties to

\footnotetext{
RT I, 8.1.2020, $10<$ www.riigiteataja.ee/akt/108012020010> accessed on 26 May 2021.

Bürgerliches Gesetzbuch <www.gesetze-im-internet.de/bgb/> accessed on 26 May 2021.

P Varul and others, Võlaõigusseadus III. Kommenteeritud väljaanne (Juura 2009) 625.

4 The first sentence of the LOA's sub-s states that 'where damage is caused as a result of a danger characteristic of an especially dangerous thing or activity, the person who controls the source of danger is liable for causing the damage regardless of the person's fault'.

5 J Lahe and I Kull, 'Motor Vehicle Operational Risk and Awarding Damages in the Event of a Traffic Accident' (2014) 5 Journal of European Tort Law 105. - DOI: https://doi.org/10.1515/jetl-2014-0005.
} 
maintain safety affects our understanding of the structure of tort law, the structure of the general composition of tort, and connections between the individual prerequisites for tort liability, while on a broader scale also affecting our thought in the field of tort law and our approach to cases emerging in legal practice.

I wrote of liability following from breach of the general duty to maintain safety for the first time in an article published in 2004. ${ }^{* 6}$ Three to four years later, Estonian courts started to implement a tort liability concept based on breach of the general duty to maintain safety. At the beginning of the 2000s, the respective concept of liability was still unfamiliar to many Estonian lawyers because not much time had passed since the entry into force of the LOA and the rules of the Civil Code of the Estonian SSR did not call for knowledge of the concept of liability proceeding from breach of the general duty to maintain safety. ${ }^{*}$ With the entry into force of the LOA, the approach to unlawfulness changed completely, and this, in turn, made it necessary to embrace the concept of the general duty to maintain safety, which has its origins in German law.

This article examines whether and to what extent the concept of liability based on the general duty to maintain safety has been recognised in Estonian legal practice. The relevant case law to date is assessed as well, for establishment of whether the adoption of the respective concept of liability has been successful and what problems still need to be resolved.

\section{Unlawfulness in general}

Under Estonian as well as German law, general tortious liability comprises three stages. As a general rule, the objective elements (Objektiver Tatbestand) - the act of the person who causes damage, damaging of the legal rights of the victim, and the causal link between the two - are verified at the first stage; unlawfulness (Rechtswidrigkeit) is verified at the second; and the tortfeasor's fault (Verschulden) is verified in the third. Verification of the prerequisites for liability usually takes place in the order presented above; principally, if it becomes evident that the causing of damage was not unlawful, there is no need to assess the tortfeasor's fault. ${ }^{* 8}$

Unlawfulness is an important precondition for tortious liability both in German and in Estonian tort law. Under BGB Section 823 paragraph 1, the protected legal interests are the life, body, health, freedom, property and other rights (especially personal rights). Similar legal interests are protected also under clauses 1-5 of the LOA's Subsection 1045(1). It has been argued that the concept of unlawfulness establishes the scope of protection of tort law: the protected legal interests and, via them, the circle of persons who are able to distinguish between the claims for damages. ${ }^{* 9}$

Under the BGB (Section 823, paragraph 2), the unlawfulness may arise also from violation of a statute. The same is provided for in clause 7 of the LOA's Subsection 1045(1). Under Section 826 of the BGB, a person who in a manner contrary to the public order intentionally inflicts damage on another person is liable toward the other person for making the damage good. This provision is very similar to that articulated in clause 8 of the above-mentioned subsection of the LOA.

In establishing unlawfulness, both German and Estonian tort law rely on two theories: the theory of the unfairness of the consequences (Erfolgsunrecht) and the theory of the unfairness of the act (Handlungsunrecht). In a situation wherein harm has been done to an absolutely protected legal interest of the injured person as a result of the direct active conduct of the tortfeasor, unlawfulness can be derived solely from the harmful consequence. Accordingly, it is not important whether the tortfeasor has, among other things, breached a duty. However, if the injured person's legal interest has been harmed by omission on the part

6 See 'The Concept of General Duties of Care in the Law of Delict' (2004) 9 Juridica International 108. In Estonia, the most extensive research into tort liability connected with a breach of the duty to maintain safety has been carried out by Iko Nõmm. See I Nõmm, 'Käibekohustuse rikkumisel põhinev deliktiõiguslik vastutus' (doctoral dissertation. University of Tartu 2013).

7 Civil Code of the Estonian SSR, passed on 12 June 1964 - ÜNT 1964, 25, 115; RT I 1997, 48, 775.

8 See FJ Säcker, R Rixecker, and H Oetker, Münchener Kommentar zum BGB (8th edn 2020). In the book's Section 823, Gerhard Wagner comments (in the first marginal note) that in the case of so-called negligence torts the objective composition of the act comprises the following three elements: the harming of a legally protected interest, anti-duty conduct, and liability-triggering causality between the anti-duty conduct and the harming of the legally protected interest. For confirmation of liability (addressed in marginal note 26), the following criteria must be met in addition: the absence of unlawfulnessprecluding circumstances, fault capacity, damage, and liability-fulfilling causality.

9 Säcker, Rixecker, and Oetker (n 8) s 823, marginal 3. 
of the tortfeasor or the harming of the injured person's legal interest is a more remote or indirect outcome of the tortfeasor's conduct, a duty that the tortfeasor has breached must be established if one is to hold the tortfeasor liable. ${ }^{* 10}$ In these situations, unlawfulness cannot be established solely on the basis of the harmful consequence. We can speak of omission of legal consequence only where the person had a duty to act.

That duty may be a statutory one (per clause 7 of Subsection 1045(1) of the LOA); cf BGB Subsection 823(2)) or a general duty to maintain safety (generale Verkehrspflicht). The Estonian Supreme Court has held that the general duty to maintain safety and a breach thereof need to be established in order for the tortfeasor to be held liable on the basis of the general composition of tort in situations wherein the cause of the damage is omission or insufficient action. ${ }^{* 11}$

Tambet Tampuu has argued that the institute of the duty to maintain safety helps to sieve out persons subject to a duty to act with care toward the victim from among all those who have caused damage by their failure to act. If the person did not have such a duty, his or her liability is out of the question. ${ }^{*} 2$ Thus, the concept of the duties to maintain safety is, on one hand, necessary for holding liable those persons who have caused damage through omission or indirectly; on the other hand, it is also a filter that allows for determining (narrowing down) the circle of tortiously liable persons. For example, if A sells B a knife that the latter then uses to kill C, A's conduct is, as such, one the of the reasons for C's death. However, holding A liable in such a situation does not seem logical or fair. The denial of A's liability is supported by the concept of duties to maintain safety: if A did not breach a duty to maintain safety by selling the knife, A cannot be held liable for causing C's death.

In the structure of the general composition of tort, breach of the duty to maintain safety must be assessed already at the level of the objective elements of the act, not at that of unlawfulness. Therefore, the only thing left to do at the level of unlawfulness is to assess unlawfulness-precluding circumstances (LOA, Subsection 1045(2)). The establishment of a breach of the duty to maintain safety also entails assessing the tortfeasor as having been externally (objectively) negligent. Nevertheless, in Estonian tort law it is possible to distinguish easily between fault and cases of duties to maintain safety because, even though breach of a duty to maintain safety can be equated with failure to exercise the required level of care under the LOA's Subsection 104(3) (addressing failure to exercise external care), under Subsection 1050(2) of the LOA negligence must be assessed subjectively also. Per that subsection, in assessing a person's fault, account is taken of that person's situation, age, education, knowledge, abilities, and other personal attributes. Thus, at the last level in the three-level tort structure, the level of fault, one must assess, with regard to liability based on breach of the duty to maintain safety, whether the person was negligent, in light of his or her personal characteristics (i.e. assess failure to exercise internal care). Even though there is no provision analogous to the LOA's Subsection 1050(2) in German law and negligence is an objective concept, German legal doctrine makes an attempt to distinguish between unlawfulness and fault also in the event of liability based on a breach of a duty to maintain safety. ${ }^{*} 13$ Therefore, for example, the person's tortious capacity must still be established at the level of fault.

\section{The meaning of the duty to maintain safety}

In German tort law, according to legal writings, liability in the case of so-called negligence torts is based on the tortfeasor's failure to exercise the required level of care. Duties that give rise to liability are called duties to maintain safety. In the decision of the German Supreme Court that laid the foundations for the concept of the duties to maintain safety in 1902, it was held that the duty to maintain safety meant taking other persons' rights fairly into account. ${ }^{*} 4$

In German tort law, the substance of the duty to maintain safety is understood as follows: anyone who gives rise to a hazardous situation (either via a dangerous thing controlled by him or her or via his or her

10 Säcker, Rixecker, and Oetker (n 8) s 823, marginal 7.

11 'Korteriühistu kohustused kahju hüvitamisel' [2012] Supreme Court Civil Chamber Judgment 3-2-1-161-12 (17 December 2012) para 10.

12 T Tampuu, Lepinguvälised võlasuhted (Juura 2017) 233.

13 Säcker, Rixecker, and Oetker (n 8) s 823, marginals 445-46.

14 Säcker, Rixecker, and Oetker (n 8) s 823, marginal 433. 
dangerous behaviour) is required to take any and all necessary and reasonable precautionary measures to prevent harming others. ${ }^{* 15}$

The duty to maintain safety should be understood analogously in Estonian law. The Estonian Supreme Court has held that the general duty to maintain safety consists of the duty to make every reasonable effort to ensure that other persons are not harmed in consequence of one's actions. ${ }^{*}{ }^{16}$ In other words, the duty to maintain safety is the duty to act, in the exercise of one's rights, in a manner that does not harm other persons. The general duty to maintain safety can be derived from Subsection 2 of Section 138 of the General Part of the Civil Code Act, which states that a right shall not be exercised in an unlawful manner or in such a way that the purpose of exercising the right is the causing of damage to another person. ${ }^{*} 17$ Furthermore, it has been held in case law that, in the most general sense, the duty to maintain safety means a duty of care on the part of a person who has given rise to or controls a dangerous situation - i.e. the duty to take any and all reasonably necessary and suitable measures to protect other persons and legally safeguarded interests against the manifestation of the threat. ${ }^{*} 18$

The person who creates a dangerous situation has a duty to maintain safety. The emergence of the duty to maintain safety is usually related to control over a situation of danger. In turn, it can be but need not be related to property as much as to simply dangerous behaviour. For instance, if a groundskeeper, in breach of contract, does not come to work and, in consequence, the pavement is not cleared of ice and snow, the groundskeeper cannot be criticised for a breach of the duty to maintain safety if a third party slips on the pavement and suffers bodily injury. However, once he engages in maintaining the pavement, he must take into account other people's rights - e.g. not leaving a snow shovel on the pavement, because others could stumble on it (this approach has received support from the judgement of the Civil Chamber of the Supreme Court in Civil Case 3-2-1-161-12, paragraph 12). It has been held in case law that the existence of the tortfeasor's duty to maintain safety may be indicated by, among other things, the manifested threat being in that person's sphere of influence, that person's actions creating trust on the part of the other person and giving the injured person an impression that the action was safe or that the tortfeasor fully controlled the threat, and the tortfeasor seeking economic gain from the dangerous activity. ${ }^{*} 19$

The duty to maintain safety cannot demand the application of impossible but reasonable precautionary measures by the person. Likewise, the general duty to maintain safety cannot demand the incurring of unreasonable costs. ${ }^{{ }^{20}}$ Accordingly, Helmut Koziol has noted that liability proceeding from a violation of a protective rule and also that following from a breach of the general duty to maintain safety involve a stricter standard of fault-based liability because in these situations the fault does not need to be related to provision for a specific legal interest; mere abstract endangering is sufficient. ${ }^{* 21}$ It has been held in case law that the more serious the threat of damage, the higher the likelihood of damage, and the lower the cost and the smaller the effort to prevent the damage, the greater the likelihood that there is a duty to take measures to prevent or eliminate the damage. ${ }^{* 2}$

Neither the BGB nor the LOA contains a direct reference to liability based on breach of the duty to maintain safety. The peculiarity of the duties to maintain safety lies in the fact that these are not set forth in legal rules and that the court must in each individual case decide on the existence of a duty to maintain safety and a breach thereof. ${ }^{* 2}$ Thus, duties to maintain safety are 'designed' in case law. This may be considered

15 W Hau and R Poseck (eds), Beck `scher Online-Kommentar zum BGB (56th edn: 1.11.2020) s 823, C Förster's marginal 102.

16 'Mittevaralise kahju rahalise hüvitamine nõuded' [2013] Supreme Court Civil Chamber Judgment 3-2-1-73-13 (20 June 2013) para 10.

17 'Korteriühistu kohustused kahju hüvitamisel' (n 11) para 10.

18 'Lepinguline kaitsekohustus. Käibekohustus' [2015] Supreme Court Civil Chamber Judgment 3-2-1-48-15 (10 June 2015) para 24.

19 'Lepinguline kaitsekohustus. Käibekohustus' (n 18) para 24.

20 See also 'Mittevaralise kahju rahalise hüvitamine nõuded' (n 16) para 11. On the required standard of conduct in various European countries, see B Winiger, E Karner, and K Oliphant, 'Essential Cases on Misconduct' [2018] Digest of European Tort Law 203. - DOI: https://doi.org/10.1515/9783110535679.

21 H Koziol, Basic Questions of Tort Law from a Germanic Perspective (Jan Sramek 2012) 250.

22 In the 'Mittevaralise kahju rahalise hüvitamine nõuded' judgement (n 16) para 11 and the judgement of 10 June 2015 in Civil Case 3-2-1-48-15, 'Lepinguline kaitsekohustus. Käibekohustus' (n 18) para 24, Thomas Raab has explained the emergence of the duty to maintain safety in a very similar way. See T Raab, 'Bedeutung der Verkehrspflichten und ihre systematische Stellung im Deliktsrecht. Juristische Schulung' (2002) 42(11) Zeitschrift für Studium und praktische Ausbildung 1044.

23 'Lepinguline kaitsekohustus. Käibekohustus' (n 18) para 24. 
problematic because subjects of law may find it difficult to anticipate what kind of level of care they should exercise in any particular situation in the opinion of the court. The answers eventually become clear on the basis of a final court decision. On the other hand, the same question could be asked in the framework of the meaning of negligence: under the LOA, Subsection 104(3), negligence means failure to exercise the required level of care, and, in principle, a person's negligence or exercise of the required level of care becomes clear in court. Nevertheless, the more extensive our case law on liability stemming from breach of the duty to maintain safety, the more predictable the standard of behaviour expected of the person by the court becomes.

The existence of a protective provision (declaring a statutory duty for the purposes of clause 7 of the LOA's Subsection 1045(1)) does not preclude liability stemming from a breach of the duty to maintain safety. In principle, the duty to maintain safety may demand that a person exercise a higher standard of care than the one established by a protective rule. ${ }^{*} 24$ The connection between protective rules and duties to maintain safety is expressed also in the fact that, theoretically, it is possible to transform all of the duties to maintain safety into protective rules. However, this is not reasonable in practice, and perhaps it is even impossible to achieve.

Duties to maintain safety as extracontractual duties are actually quite similar to contractual protective duties. The latter emerge solely for the parties of a contract with respect to one another or, for the purposes of the LOA's Section 80 or Section 81, with respect to third parties. If the victim suffers damage due to a breach of a contractual protective obligation, the victim usually must file a claim for damages under contract law (LOA, Subsection 1044(2)). Only in the event of the victim's death or bodily injury / damage to health, the victim always has a choice of the legal basis for the claim (LOA, Subsection 1044(3)).

Duties to maintain safety protect, above all, the absolutely safeguarded legal interests, but even their scope of protection may not be limited to those absolutely safeguarded interests. ${ }^{* 25}$

\section{Development of Estonian case law pertaining to liability based on a breach of the duty to maintain safety}

It is somewhat surprising to note that it was Tallinn Court of Appeal (not, as one might expect, the Supreme Court) that led the way in applying a concept of tortious liability based on breach of the duty to maintain safety and in developing respective case law. Tallinn Court of Appeal already referred to the existence of the duty to maintain safety and the meaning thereof four years before the Supreme Court rendered its first respective judgement. More specifically, in its decision dated 16 December 2008, Tallinn Court of Appeal held in connection with the duties and liability of the keeper of an online commenting environment that it followed from the general definition of the duty to maintain safety that anyone who creates a source of danger in the private sector that may in a recognisable way pose a threat of harming the rights of third parties is required to take reasonable measures to prevent the harming of the rights. ${ }^{{ }^{2} 6}$

A couple of years later, Tallinn Court of Appeal clearly applied liability based on a breach of the duty to maintain safety. At question was a case wherein the victim was a motorcyclist who had ridden into fallen telecommunications lines and had a road accident as a result thereof. The court of appeal noted that the owner of the telecommunications infrastructure (one of the defendants) did not make an effort to ensure the safety of the telecommunications line running across the road to the users of the carriageway. The fact that the owner of these lines had concluded a contract for work to maintain the telecommunications lines does not prove that the owner carried out its duty to maintain safety in such a manner that information on downing or breakage of a telecommunications line would be received within reasonable time, as would allow for preventing a road hazard. ${ }^{*} 2$

24 Tampuu (n 12) 234.

25 For further information on the protected legal interests, see Nõmm (n 6) 96-106.

26 Tallinn Court of Appeal Judgment in Civil Case 2-06-9067 (16 December 2008). For purposes of clarity, it should be noted that the definition (existence) of the duty to maintain safety is referred to also in a few earlier decisions - for instance, in the Harju District Court judgement of 25 June 2007 in Civil Case 2-06-720 (para 10) and in the Tallinn Court of Appeal judgement of 9 April 2007 in Civil Case 2-05-15618 (para 11). However, these decisions do not say anything substantive or more detailed about the nature of the duties to maintain safety.

27 Tallinn Court of Appeal Judgment in Civil Case 2-09-32485 (28 October 2011). 
In a decision dated 5 April 2012, the court of appeal discussed the duty to maintain safety on the part of the organiser of a kayak trip. The court held that, upon organising a kayak competition on rough seas, the organiser was under the obligation to ensure supervision of the safety of the participants in such a way that the location of all participants was observable at all times. The court of appeal was of the opinion that, while the defendant was not required to ensure that the kayaks of the participants did not capsize, the defendant had a duty to ensure sufficient monitoring for noticing the upturning of a kayak swiftly enough and ensuring that participants who have found themselves in trouble receive help and, thus, prevent threats to the participants' life. ${ }^{*} 8$

In its judgement of 28 September 2012, the court of appeal discussed the duty to maintain safety with regard to a house-owner on whose immovable property a postman who had put a newspaper in a mailbox slipped on ice and suffered bodily injury: the court held that the defendant knew that the postman was delivering mail to the mailbox there and using the pathway in question to reach the mailbox on the property. Therefore, the defendant was required to take reasonably necessary appropriate and affordable measures to protect the claimant from falling while on the immovable and protect against related damage to his health. ${ }^{* 29}$

With merely a handful of cases addressing such matters, the case law of the Estonian Supreme Court is nowhere near extensive as regards liability based on breach of the duty to maintain safety. The first time the Supreme Court referred to the duty to maintain safety in the reasons for a decision was with its judgement of 17 December 2012, where the court held that, given the general duty to maintain safety, the flat-owners (not the flat-owners' association) had a duty to remove snow and ice from the roof of the building in question and a duty to warn car-owners with regard to this. The court explained that, following the principle of good faith and the general duty to maintain safety, flat-owners must make every effort not to harm other persons while owning, possessing, and using their residential building. The flat-owners' association established by the owners of the residential building does not have such a duty. ${ }^{*} 30$

Next, the Supreme Court discussed the duty to maintain safety on the part of the owner of a block of flats (in a situation wherein said person lets the flats), doing so in greater detail. The Supreme Court held that the defendant, who owned a block of flats, had created a dangerous situation for the victim because there was a hole in the wall along the stairwell of the building through which the claimant and other persons could fall - as, indeed, the claimant did - and that the lighting of the stairwell had been implemented in such a manner that it did not ensure safe descent for a person using the stairwell for the first time. The dangerousness arose from the combined effect of two factors: the hole and the lighting. ${ }^{*}{ }^{*}$

In addition, the Supreme Court has discussed the duty to maintain safety on the part of a skydiving organiser (a flight club). The Supreme Court held that the general duty of an organiser of parachute jumps is, in the most general sense, the organisation of safe parachute jumps and the sufficient training and instruction of jumpers. The chamber drew attention to the fact that, since the organisation of parachute jumps entails a heightened risk to the life and health of people, the organiser is under an extensive duty to maintain safety. Among others, the organiser has an obligation to warn the jumper against possible risks and to explain how to act in a situation of danger. In addition, the organiser must teach the participants how to perform a parachute jump and, before they make a jump, check whether the person in question has the required knowledge and skills. During a jump, it must be made certain that the person makes the jump correctly. ${ }^{*} 2$

As demonstrated by the above case-law overview, the courts have assessed the existence and substance of the duty to maintain safety within the framework of relatively specific situations. In consequence, the case law to date is of relatively little help in foreseeing what the court will consider to be the substance of the duty to maintain safety in a different situation. For instance, in a recent case, the court had to assess the duty to maintain safety on the part of the owner of a public park because a tree had fallen in the park and

28 Tallinn Court of Appeal Judgment in Civil Case 2-10-55812 (5 April 2012).

29 Tallinn Court of Appeal Judgment in Civil Case 2-11-26543 (28 September 2012). The court cases are notable because at that time the Supreme Court had not yet said a word about liability stemming from a breach of the duty to maintain safety.

30 'Korteriühistu kohustused kahju hüvitamisel' (n 11) para 10.

31 'Mittevaralise kahju rahalise hüvitamine nõuded' (n 16) para 11. This case has been discussed in greater detail by J Lahe and I Kull - E Karner and BC Steininger, European Tort Law Yearbook 2013 (De Gruyter 2014) 219-21. - DOI: https:// doi.org/10.1515/tortlaw-2014-0110.

32 'Lepinguline kaitsekohustus. Käibekohustus' (n 18) para 24. 
caused physical injuries to someone. In that case, the court of appeal, broadly speaking, decided that the owner of a public park has performed the duty to maintain safety with regard to visitors of the park if having hired an arborist and carried out maintenance cutting of the trees. ${ }^{*} 33$

On the basis of the above-mentioned court decisions, it can nevertheless be clearly concluded that the concept of liability stemming from a breach of the duty to maintain safety is no longer unknown in Estonian case law and that the courts understand quite well which cases of causing unlawful damage call for its application.

\section{The burden of proof for breach of the duty to maintain safety}

A problematic question remaining in the framework of liability based on the duty to maintain safety is who bears the burden of proving a breach of the duty to maintain safety. According to the general rule in force in German law, the claimant must prove that the prerequisites for the claim are met. ${ }^{*} 34$ This means, first of all, proving of the objective elements of the act, which, as a rule, is indicative of unlawfulness as well. The tortfeasor must, in turn, prove the existence of liability-precluding circumstances. ${ }^{*} 35$

In Estonian law, however, the situation is complicated by the fact that, under the LOA's Subsection 1050(1), the tortfeasor must prove the absence of fault, as there is a presumption of the tortfeasor's fault. Therefore, the Supreme Court has expressed the view that, since, according to the position generally recognised in the legal theory, the general duty to maintain safety means the duty of care; negligence is one of the forms of fault under Subsection 104(2) of the LOA; and, under its Subsection 1050(1), the fault of the person who caused unlawful damage is presumed, the defendant bears the burden of proving that the defendant did not breach the duty to maintain safety. For this burden of proof to be formed, the claimant must have proved that damage was caused in consequence of a threat created by the defendant and that the defendant's fault - i.e. a breach of the general duty to maintain safety - is not clearly precluded, given the circumstances of the case. ${ }^{*} 36$

The line of argument taken by the Supreme Court is, in itself, understandable. However, given the structure of the general composition of tort, a breach of the duty to maintain safety is an element of unlawfulness rather than fault. One can argue that, in the event of liability based on a breach of the duty to maintain safety, unlawfulness and fault as prerequisites for liability are entwined or fused. Since the claimant must bear the burden of proof of unlawfulness, I find it a more logical solution to have the claimant prove, among other things, also the tortfeasor's breach of the duty to maintain safety.

Liability based on breach of the duty to maintain safety is, for the purposes of the structure of tortious liability, very similar to liability based on breach of a statutory duty (see clause 7 of the LOA's Subsection 1045(1)). If the claimant relies in its claim on breach of a safeguarding rule by the tortfeasor, the claimant must clearly prove breach of the respective safeguarding rule too. Demonstrating breach of the safeguarding rule may encompass, among other things, proving the fault of the tortfeasor, because the safeguarding rules of tort law usually require conduct constituting fault on the part of the obligated person. Therefore, there is a difficulty in seeing any fundamental difference between the two liability compositions, which may lead to a question of whether these two situations differing in the division of the burden of proof is indeed justified.

I find that placing the burden of proving a breach of the duty to maintain safety on the claimant would not make much of a difference with regard to the burden of proof in practice. For example, if A falls into an open manhole, A needs to demonstrate, if wishing to prove a breach of the duty to maintain safety, that there was an open manhole on B's immovable property and that A fell into it. Breach of the duty to maintain safety by B can be concluded from these circumstances. At the same time, B has an opportunity to, for

33 'Pargipidaja käibekohustus' [2020] Tallinn Court of Appeal Judgment in Civil Case 2-18-8345 (24 September 2020). At the time of writing of this article, the respective case was being adjudicated by the Supreme Court.

34 Säcker, Rixecker, and Oetker (n 8) s 823, marginal 89.

35 Hau and Poseck (n 15) s 823, marginal 42.

36 'Mittevaralise kahju rahalise hüvitamine nõuded' (n 16) para 10. Such a division of the burden of proof seems to be supported also by Tampuu (n 12) 235-36. 
instance, prove at any time that B checked for the presence of manhole covers with sufficient regularity i.e. that $\mathrm{B}$ made every reasonable effort to prevent the risk emanating from the manhole to third parties.

In conclusion, it could be argued that the fewer exceptions there are to the overall burden of proof, the clearer it is for the parties to the proceedings what they need to prove in order to defend their position.

\section{Conclusion}

Tortious liability based on breach of the duty to maintain safety, the core topic discussed in this article, is merely one example of how concepts developed in German legal scholarship and case law have reached Estonian legal practice. It can be argued that the definition, substance, and scope of application of the duty to maintain safety is looked at very similarly in German and Estonian case law.

Analysis of relevant Estonian case law enables one to conclude that the concept of liability based on breach of the duty to maintain safety has been successfully adopted by the Estonian courts. Naturally, the small number of court decisions does not allow one to draw extensive conclusions about whether the standard of conduct expected of persons by the courts (i.e. the standard of care) has become too high or low. Obviously, this is largely a matter of estimation.

According to Estonian case law, in contrast to German law, the burden of proof for breach of the duty to maintain safety lies with the tortfeasor. This difference can be explained with the aid of Subsection 1050(1) of the LOA, yet the justifiability thereof is subject to some doubt, especially visible when one compares liability based on breach of the duty to maintain safety with liability based on a safeguarding rule.

Finally, one can note with satisfaction that liability based on breach of the duty to maintain safety is a successful transplant from German to Estonian tort law. Perhaps the biggest threat to the application of such liability is that the courts will transform it into liability similar to strict liability. This might come about if the courts were to start substantiating the general duty to maintain safety as a duty to 'refrain from' harming another person or as a duty to 'ensure' non-harming of another person. From the decisions discussed in this article, it can be argued that this has not happened yet. 